\title{
Pheochromocytoma and Paraganglioma: Progress on all Fronts
}

\author{
Anne-Paule Gimenez-Roqueplo • Arthur S. Tischler
}

Published online: 13 January 2012

(C) Springer Science+Business Media, LLC 2012

This special issue of Endocrine Pathology, together with a parallel issue of Hormone Metabolic Research compiles state-of-the-art reviews and selected original research findings presented at the September 2011 International Symposium on Pheochromocytoma and Paraganglioma (ISP 2011) [1-17]. This symposium, hosted by Pierre-Francois Plouin and Anne-Paule Gimenez-Roqueplo in Paris, France, attracted a record number of participants following ISP 2008 in Cambridge, UK and ISP 2005 in Bethesda, MD, USA. These symposia are multidisciplinary gatherings of physicians and basic scientists intended to rapidly advance understanding and treatment of pheochromocytoma and extra-adrenal paraganglioma. They are held under the aegis of the Pheochromocytoma and paraganglioma RESearch Support ORganization (PRESSOR, http://www.pressor.org), which was established in the Spring of 2004 following a 2003 workshop at Cold Spring Harbor organized by James Watson and William M Manger.

\section{A.-P. Gimenez-Roqueplo}

Assistance Publique-Hôpitaux de Paris,

Hôpital Européen Georges Pompidou Service de Génétique,

F-75015 Paris, France

e-mail: anne-paule.gimenez-roqueplo@egp.aphp.fr

A.-P. Gimenez-Roqueplo

Sorbonne Paris Cité, Faculté de Médecine,

Université Paris Descartes,

F-75006 Paris, France

A.-P. Gimenez-Roqueplo

INSERM, UMR970, Paris Cardiovascular Research Center,

F-75015 Paris, France

\author{
A. S. Tischler $(\bowtie)$ \\ Department of Pathology, Tufts Medical Center, \\ 800 Washington Street, \\ Boston, MA 02111, USA \\ e-mail: atischler@tuftsmedicalcenter.org
}

As evident from the ISP2011 papers, it is now an exciting time in the pheochromocytoma/paraganglioma (PCC/PGL) field. Not very long ago these tumors were essentially curiosities, considered to be sporadic in $90 \%$ of cases, almost always benign, and associated with hereditary tumor syndromes involving only three genes, RET, VHL, and NF1. Recent developments in molecular genetics have expanded the spectrum of disorders and, accordingly, increased the complexity of information that clinicians and researchers must grasp in order to provide state of the art care and to make further progress. At least $30 \%$ of the tumors are now known to be hereditary and germline mutations of at least ten genes can cause them to develop. The rate of new gene discovery has accelerated rapidly (Fig. 1), and there are likely more genes to come. Genotype-phenotype correlations have been identified, including differences in tumor distribution, catecholamine production and risk of metastasis. Further, types of tumors not previously associated with PCC/PGL are now considered in the spectrum of hereditary disease. Important new findings are that mutations of succinate dehydrogenase genes $S D H A, S D H B, S D H C$, and $S D H D$ (collectively abbreviated $S D H \mathrm{x}$ ) are responsible for a large percentage of hereditary tumors, and that $S D H B$ mutations are strongly correlated with extra-adrenal location, metastasis, and poor prognosis. Further, gastrointestinal stromal tumors and renal cell carcinomas are new types of tumors associated with $S D H x$ mutations.

From a molecular standpoint, PCC/PGL with different underlying genotypes segregate into two clusters, with characteristic differences in their transcriptomes, signaling pathways and expression of biomarkers. $V H L$ and $S D H \mathrm{x}$ mutations (cluster 1) are associated with "pseudo-hypoxic" signaling, while mutations of the other susceptibility genes are associated with alterations of RAS signaling, protein trafficking and a variety of other cell functions (cluster 2). 


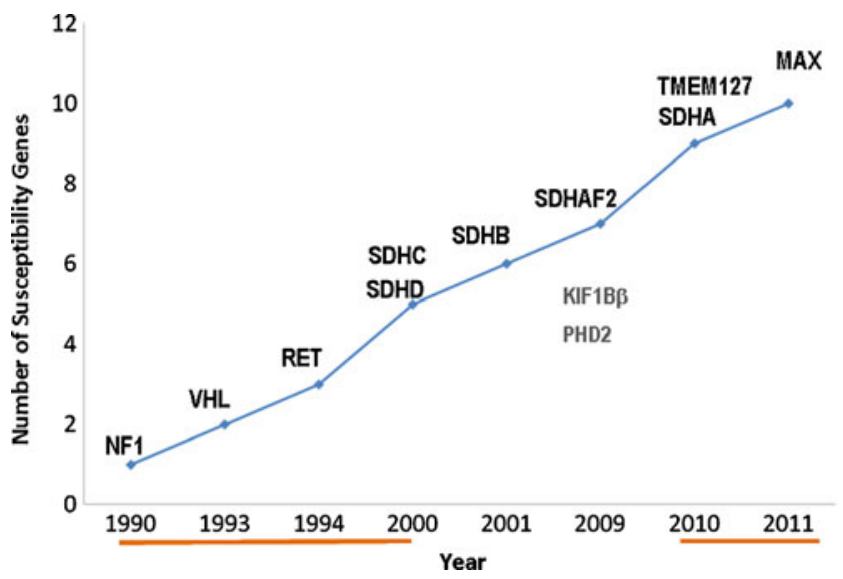

Fig. 1 The accelerating rate of discovery of susceptibility genes for pheochromocytoma and extra-adrenal paraganglioma. Figure courtesy of Dr Patricia Dahia (Gimenez-Roqueplo AP, Dahia PL and Robledo M), Update in the Genetics of Paraganglioma and Pheochromocytoma and Hereditary syndromes [7]

The different pathways present a variety of distinct potential drug targets, some of which have already been tested in experimental models.

These developments have important implications for pathologists. First, there are requirements for awareness of new disease associations; for example, the need to communicate to clinicians that concurrence of pheochromocytoma and GIST is probably not a coincidence. Second, it must be recognized that pathology findings cannot be fully understood without knowledge of tumor genotype. That point is made by Favier et al. in this issue of EP, who show that a previously reported association of increased VEGF expression with malignancy can actually be explained by the fact that malignant PCC/PGL are over-represented in cluster 1 and therefore over-express VEGF, but that VEGF expression does not apparently distinguish between benign and malignant tumors within the cluster. Similar considerations may pertain to tumor size, local invasiveness, and other pathology findings.

Pathologists also have new functions to perform in patient management and new tools with which to perform them. As discussed by Eisenhofer et al., anatomic pathologists can help to triage patients for appropriate, cost effective genetic testing by immunohistochemical staining for SDHB protein, which is lost in tumors with any SDHx mutation, or for SDHA, which is lost only with mutation of the SDHA gene. Further, clinical pathologists can now test for metabolites of catecholamines and their biosynthetic intermediaries not only to screen for the presence of tumor but also to point to specific mutations, stratify risk of metastasis and find small metastases that might otherwise go undetected. For example, pheochromocytomas associated with RET or NF1 mutations produce epinephrine, reflected by elevated levels of its metabolite, metanephrine, in plasma or urine. Pheochromocytomas in von Hippel-Lindau disease are noradrenergic and cause solitary increases in concentrations of normetanephrine, while tumors with $S D H B$ or $S D H D$ mutations can also produce norepinephrine but often produce dopamine and cause increases in methoxytyramine levels, which are also associated with malignancy. Future roles of pathology will no doubt include immunohistochemical identification of specific markers to guide the selection of targeted therapies.

Clinical implications of the new biological understanding are discussed in detail in the companion ISP2011 papers in Hormone Metabolic Research. In general, a constellation of findings including patient age at presentation, tumor location, biochemical profile, and presence of metastases helps to guide cost-effective genetic testing of patents who present with PCC/PGL and no clinical features indicating a specific tumor syndrome. The results of genetic testing in turn guide management of patients, genetic counseling and testing of family members. An important consideration is that underlying mutations in tumors can affect the sensitivity of functional imaging modalities. For example, ${ }^{123}$ I-metaiodobenzylguanidine scintigraphy and ${ }^{18} \mathrm{~F}$-6-fluorodopamine or ${ }^{18} \mathrm{~F}$-6-fluorodihydroxphenylalanine positron emission tomography (PET), which have good sensitivity for imaging adrenal pheochromocytomas, are often less reliable for extra-adrenal paragangliomas and metastases with $S D H B$ mutations. Consequently, ${ }^{18} \mathrm{~F}$ fluorodeoxyglucose PET is recommended for the latter. This difference might reflect both decreased capacity for catecholamine transport and storage and increased energy demands.

Current consensus is that long-term follow-up to screen for recurrent and metastatic disease is required for all patients after surgery for pheochromocytomas and paragangliomas, whether hereditary or apparently sporadic. Questions now being considered are how often follow-up screening should be performed, how it should be performed, and how patients should be stratified according to level of risk. Patients with $S D H B$ mutations are at particularly high risk and tend to have large extra-adrenal tumors that often produce minimal quantities of catecholamines and substantial amounts of dopamine. Screening in these patients should therefore include measurements of methoxytyramine, and possibly also chromogranin A, together with periodic thoracic-abdominal and pelvic imaging.

There have been several exciting accompaniments to the scientific progress resulting from PCC/PGL research. One has been the establishment of international multicenter collaborations providing infrastructure for rapid implementation of clinical trials. The FIRSTMAPPP trial (First International Randomized Study in Malignant Progressive Pheochromocytoma and Paraganglioma, http://clinicaltrials. gov/ct2/show/NCT01371201) is one example, jointly initiated by members of the PRESSOR consortium and the European Network for the Study of Adrenal Tumours (ENS@T, http://www.ensat.org). A consortium of clinicians 
and investigators modeled on PRESSOR has also been established in Japan. In the United States, a new National Center for Advancing Translational Sciences, established by the National Institutes of Health, will included a program focused on development of new treatments for rare and neglected diseases (http://nih.gov/news/health/dec2011/ od-23.htm). Other positive developments apparent at ISP2011 are the important roles of women scientists in the field, particularly in genetics, tumor biology and model systems, and the contributions of new, young, talented investigators. Thus, the vision of Drs. Watson and Manger set forth at Cold Spring Harbor in 2003 is bearing fruit.

The next ISP will be held in Kyoto, Japan in the fall of 2014. Judging from the accelerating progress in the field, many scientific achievements can be expected between now and then. The present series of articles in Endocrine Pathology and Hormone Metabolic Research should whet our appetite for the next advances.

\section{References}

1. Eisenhofer G, Schott M, Bornstein S. Pheochromocytoma and paraganglioma: recent progress and new vistas for improved patient care. Horm Metab Res 2012; 44: in press

2. Amar L, Fassnacht M, Gimenez-Roqueplo AP, Januszewicz A, Prejbisz A, Timmers H, Plouin PF. Long-term postoperative follow-up in patients with apparently benign pheochromocytoma and paraganglioma. Horm Metab Res 2012; 44: in press

3. Buffet A, Venisse A, Nau V, Roncellin I, Boccio V, Le Pottier N, Boussion M, Travers C, Simian C, Burnichon N, Abermil N, Favier J, Jeunemaitre X, Gimenez-Roqueplo AP. A decade (2001-2010) of genetic testing for pheochromocytoma and paraganglioma. Horm Metab Res 2012; 44: in press

4. Eisenhofer G, Vocke CD, Elkahloun A, Huynh TT, Prodanov T, Lenders JWM, Timmers HJ, Benhammou JN, Linehan WM, Pacak $\mathrm{K}$. Genetic screening for von Hippel-Lindau gene mutations in non-syndromic pheochromocytoma: low prevalence and falsepositives or misdiagnosis indicates a need for caution. Horm Metab Res 2012; 44: in press

5. Elston MS, Meyer-Rochow GY, Holdaway I, Conaglen JV. Patients with RET D631Y mutations most commonly present with pheochromocytoma and not medullary thyroid carcinoma. Horm Metab Res 2012; 44: in press

6. Fishbein L, Bonner L, Torigian DA, Nathanson KL, Cohen DL, Pryma D, Cengel K. Combined 131I-MIBG and EBRT treatment provides durable local control in patients with malignant pheochromocytoma and paraganglioma. Horm Metab Res 2012; 44: in press

7. Gimenez-Roqueplo AP, Dahia PL, Robledo M. Update in the genetics of paraganglioma and pheochromocytoma and hereditary syndromes. Horm Metab Res 2012; 44: in press

8. Lahlou-Laforêt K, Consoli SM, Jeunemaitre X, Gimenez-Roqueplo AP. Presymptomatic genetic testing in minors at risk of paraganglioma and pheochromocytoma: our experience of oncogenetic multidisciplinary consultation. Horm Metab Res 2012; 44: in press

9. Lefebvre S, Borson-Chazot F, Kryza N,Wion N, Schillo F, Peix JL, Brunaud L, Finat A, Calender A, Giraud S. Screening of mutations in genes that predispose to hereditary paragangliomas and pheochromocytomas. Horm Metab Res 2012; 44: in press

10. Mannelli M, Dralle H, Lenders JWM. Perioperative management of pheochromocytoma/paraganglioma: is there a state of the art? Horm Metab Res 2012; 44: in press

11. Persu A, Lannoy N, Maiter D, Mendola A, Montigny P, Oriot P, Vinck W, Garin P, Hamoir M, Vikkula M. Prevalence and spectrum of SDHx mutations in pheochromocytoma and paraganglioma from Belgium: an update. Horm Metab Res 2012; 44: in press

12. Plouin PF, Fitzgerald P, Rich T, Ayala-Ramirez M, Perrier ND, Baudin E, Jimenez C. Metastatic pheochromocytoma and paraganglioma: focus on therapeutics. Horm Metab Res 2012; 44: in press

13. Porzig A, Matthay KK, Dubois S, Pampaloni M, Damon L, Hawkins R, Goldsby R, Hollinger F, Fitzgerald P. Proteinuria is associated with acute respiratory distress syndrome in patients with metastatic pheochromocytoma or paraganglioma. Horm Metab Res 2012; 44: in press

14. Spetz J, Dalmo J, Nilsson O, Wängberg B, Ahlman H, ForssellAronsson E. Specific binding and uptake of 131I-MIBG and 111 In-octreotide in malignant paraganglioma - tools for choice of radionuclide therapy. Horm Metab Res 2012; 44: in press

15. Timmers HJ, Taieb D, Pacak K. Current and future anatomical and functional imaging approaches to pheochromocytoma and paraganglioma. Horm Metab Res 2012; 44: in press

16. Zelinka T, Petrák O, Hana T, Holaj R, Strauch B, Kršek M, Vránková A, Musil Z, Dušková J, Michalský D, Novák K,Widimský jr. J. High incidence of cardiovascular complications in pheochromocytoma. Horm Metab Res 2012; 44: in press

17. Zovato S, Kumanova A, Demattè S, Sansovini M, Bodei L, Di Sarra D, Casagranda E, Severi S, Ambrosetti A, Schiavi F, Opocher G, Paganelli G. Peptide receptor radionuclide therapy (PRRT) in individuals with neck or mediastinal paraganglioma (PGL). Horm Metab Res 2012; 44: in press 